\title{
Measurement of serum and peritoneal fluid LH concentrations as a diagnostic tool for human endometriosis
}

\author{
J. C. Illera'1,2, G. Silván¹, M. J. Illera¹,3, C. J. Munro², \\ B. A. Lessey ${ }^{3}$ and M. Illera ${ }^{1}$ \\ ${ }^{1}$ Department of Animal Physiology, School of Veterinary Medicine, University Complutense, \\ 28040 Madrid, Spain; ${ }^{2}$ Department of Population Health and Reproduction, School of \\ Veterinary Medicine, University of California, Davis, CA 95616, USA; and ${ }^{3}$ Department of \\ Obstetrics and Gynecology, School of Medicine, University of North Carolina Chapel Hill, \\ NC 27599, USA
}

\begin{abstract}
A rapid, sensitive enzymeimmunoassay for the measurement of $\mathrm{LH}$ concentrations in serum and peritoneal fluid samples of healthy women and women with endometriosis is reported. The ligand ( $\mathrm{LH})$ was captured by a readily available, widely used and well-characterized monoclonal antibody (mAb, 518B7) generated against the $\beta$ subunit of bovine $\mathrm{LH}$. This $\mathrm{mAb}$, although specific for $\mathrm{LH}$, shows very little species specificity and detects $\mathrm{LH}$ by radioimmunoassay in humans. A polyclonal antiserum raised in rabbits against hCG was conjugated to horseradish peroxidase and was used as the second antibody signal. This anti-hCG antiserum crossreacts with LH. The enzymeimmunoassay uses the standard human LH (hLH) preparations (NIADDK-hLH-I-3, AFP-827OB) and results are based on the relative concentrations of $\mathrm{LH}$ in serum and peritoneal fluid. Total assay time was $<3 \mathrm{~h}$. The range of the standard curve was $0.002-0.500 \mathrm{ng}$ LH per well and the lowest concentration of hLH that could be distinguished from zero concentration was $0.15 \pm 0.02 \mathrm{ng} \mathrm{ml}^{-1}$ serum and $0.058 \pm 0.021 \mathrm{ng} \mathrm{ml}^{-1}$ peritoneal fluid. Clinical
\end{abstract}

diagnostic parameters for the LH enzymeimmunoassay showed a sensitivity of $85.71 \%$, specificity $92.50 \%$, efficiency $88.54 \%$, positive predictive value $94.11 \%$ and negative predictive value $82.22 \%$. The study was retrospective. Serum LH concentrations of women with endometriosis were $13.67 \pm 7.21 \mathrm{ng} \mathrm{ml}^{-1}$, whereas serum LH concentrations of women in the control group were $4.52 \pm 2.03 \mathrm{ng} \mathrm{ml}^{-1}$. One-way ANOVA showed significant differences $(P<\mathbf{0 . 0 0 1})$ between women with endometriosis and control groups. Women in the control group had peritoneal fluid $\mathrm{LH}$ values of $5.65 \pm 2.43 \mathrm{ng} \mathrm{ml}^{-1}$, whereas peritoneal fluid $\mathrm{LH}$ values of $64.06 \pm 16.44 \mathrm{ng} \mathrm{ml}^{-1}$ were obtained in women with endometriosis $(P<0.001)$. A cycle-dependent pattern of serum and peritoneal fluid $\mathrm{LH}$ concentration was observed in women in the control group, which was not observed in the peritoneal fluid of the group with endometriosis. The application of this assay to serum or peritoneal fluid samples provides the attractive possibility that it could be included in the panel of markers used for diagnosis of endometriosis.

\section{Introduction}

Endometriosis is defined as the presence of endometrial glands and stroma in ectopic locations (Sampson, 1924). Peritoneal fluid of women undergoes alterations in volume (Drake et al., 1980; Koninckx et al., 1980a) and composition during the menstrual cycle (Syrop and Halme, 1987). The peritoneal fluid microenvironment is sensitive to the influences of endometriosis due in part to the presence of activated macrophages (Halme et al., 1984). Specific changes include alterations in peritoneal fluid proteins (Haney et al., 1981; Badawy et al., 1984; Nothnick et al., 1994), cytokines (Weinberg et al., 1991; Khorram et al., 1993; Ryan et al., 1995; Punnonen et al., 1996; Harada et al., 1997; Hsu et al., 1997), growth factors (Oosternlynck

Email: vefis07@sis.ucm.es et al., 1994; Huang et al., 1996; Taskin et al., 1996) and hormones (Loumaye et al., 1984; Bouckaert et al., 1986; Chew et al., 1987; Barry-Kinsella et al., 1994). Such alterations have been linked to infertility with effects on sperm function (Sueldo et al., 1987; Coddington et al., 1992; Aeby et al., 1996), embryo toxicity (Morcos et al., 1986; Taketani et al., 1992) and uterine receptivity (Hahn et al., 1986; Lessey et al., 1994). Furthermore, such changes may be useful for the diagnosis of endometriosis in some women.

$\mathrm{LH}$ participates in the regulation of the menstrual cycle leading to folliculogenesis, ovulation, and eventual fertilization and embryo implantation. Measurement of serum LH concentrations in women has been an important procedure for understanding the endocrine changes around the time of implantation and for detection of the preovulatory surge (Yoshida et al., 1987). During the menstrual cycle, serum LH concentrations peak at the time of 
ovulation (Dufau et al., 1976). The role of $\mathrm{LH}$ in human peritoneal fluid has not yet been elucidated.

A cycle-dependent pattern of peritoneal fluid $\mathrm{LH}$ concentrations has been observed during the menstrual cycle with concentrations that are greater than or equal to those of serum (Bouckaert et al., 1986; Syrop and Halme, 1987), although this has not been observed in all studies (Kim-Brjörlund et al., 1991). On the basis of its carbohydrate (sialic acid) content, the presence of $\mathrm{LH}$ in peritoneal fluid can potentially be explained by diffusion from the ovarian vasculature (Bouckaert et al., 1986). Previous reports have also documented higher peritoneal fluid $\mathrm{LH}$ concentrations in women with endometriosis (Chew et al., 1990), although no study has compared concomitant serum and peritoneal fluid $\mathrm{LH}$ concentrations in normal patients and those with endometriosis. Serum LH concentrations are increased in women with luteinized unruptured follicle syndrome, many of whom have endometriosis (Koninckx et al., 1980b). The aims of the present study were: (i) to validate a well-established sandwich LH enzymeimmunoassay in several species (Illera et al., 1995a, 1996, 1997; Munro et al., 1997) for estimating the concentrations of LH in human serum and peritoneal fluid; and (ii) to establish whether the measurement of serum and peritoneal fluid LH concentrations could be a diagnostic tool for human endometriosis. The assay can be completed in $<3 \mathrm{~h}$, is simple to perform and could potentially be included in the panel of markers used for detection of endometriosis.

\section{Materials and Methods}

\section{Subjects}

The study was performed retrospectively on two groups of women. The first group consisted of women $(n=32$; aged 24-38 years) who were seen in the Division of Reproductive Endocrinology and Fertility at the University of North Carolina for investigation of infertility. Each of these women was diagnosed with endometriosis by laparoscopy, at which time peritoneal fluid, serum and endometrial biopsies were obtained. Each patient signed informed consent to participate in these studies and all samples used in this study were obtained in accordance with the Committee for the Protection of Human Subjects at the University of North Carolina. Histological dating was determined on each endometrial sample according to the dating criteria of Noyes et al. (1950). The stage of endometriosis was recorded according to the revised classification of The American Society for Reproductive Medicine (ASRM, 1997). The second group consisted of women with regular menstrual cycles $(n=20$; control group) who underwent laparoscopic tubal ligation either by cautery or clips. None of the women entered in this study had received hormone therapy within the previous 30 days and none had been exposed to injectable progestins during the previous 6 months. Both groups were divided into three categories according to the stage of the menstrual cycle as
Table 1. Demographics of patients with and without endometriosis

\begin{tabular}{lcc}
\hline & Control & Endometriosis* \\
\hline $\begin{array}{l}\text { Number of patients } \\
\text { Age }\end{array}$ & $n=20$ & $n=32$ \\
Stage of cycle & $28.11 \pm 4.2$ & $31.16 \pm 6.78$ \\
$\quad$ Early proliferative & $5(25.00 \%)$ & $9(28.12 \%)$ \\
$\quad$ Proliferative & $9(45.00 \%)$ & $9(28.12 \%)$ \\
$\quad$ Secretory & $6(30.00 \%)$ & $14(43.75 \%)$ \\
\hline
\end{tabular}

*Stage of endometriosis: stage I: $n=5(15.62 \%)$; stage II: $n=14(43.75 \%)$; stage III: $n=6(18.75 \%)$; stage IV: $n=7(21.89 \%)$.

follows: early proliferative (days 1-7), proliferative (days 8-14), and secretory phase (days 15-27); this division was based on the last menstrual period and endometrial histology dating according to Noyes et al. (1950). More detailed information on the women studied is shown (Table 1).

Non-paired serum and peritoneal fluid samples obtained from the patients diagnosed as endometriosis positive ( $n=56$ samples) and from healthy women ( $n=40$ samples) that came to the Division of Reproductive Endocrinology and Fertility at the North Carolina University Hospital were used for determining the clinical diagnostic parameters.

\section{Collection of blood and peritoneal fluid samples}

Serum was obtained by venepuncture at the time of laparoscopy. Laparoscopy was performed for evaluation of endometriosis or at the time of tubal ligation. Peritoneal fluid samples $(2-10 \mathrm{ml})$ were obtained from the cul-de-sac at the time of laparoscopy, using a metal suction cannula attached to a $10 \mathrm{cc}$ syringe. Volumes of peritoneal fluid ranged from 2 to $>10 \mathrm{cc}$. The sample was not used if blood mixed with peritoneal fluid was found at the time of laparoscopy. Samples were placed on ice before being transported to the laboratory and were centrifuged immediately at $2000 \mathrm{~g}$ for $15 \mathrm{~min}$ at $4^{\circ} \mathrm{C}$. Supernatants were divided into aliquots and stored at $-80^{\circ} \mathrm{C}$ until assayed.

\section{Preparation of hCG-horseradish peroxidase conjugate}

Antiserum for the enzyme-labelled, second antibody signal was polyclonal anti-hCG antiserum (R76; Department of Population Health and Reproduction, University of California, Davis, CA) raised against purified hCG (CR-121; R. Canfield, Department of Medicine, Columbia University, New York, NY). The purified IgG fraction of the anti-hCG antiserum (R76) was conjugated to sodium-periodateactivated horseradish peroxidase (HRP; EC 1.11.1.7., type VI, Sigma Chemical, St Louis, MO) by a modification of the method of Wilson and Nakane (1978), as described by Munro et al. (1997).

The optimum concentration and dilution of this 
conjugate was determined by checkerboard titration, as the coating concentration of the 518B7 had been established previously in this laboratory and by Spearow and Trout (1987). Appropriate dilution of the anti-hCG-horseradish peroxidase was chosen to achieve both sufficient colour development and low non-specific binding in the enzymeimmunoassay.

\section{Enzymeimmunoassay}

Dynatech Immulon I (Fisher Scientific, Santa Clara, CA) or Nunc Maxisorb (Krape, Madrid) 96-well microtitre plates were coated with $100 \mu \mathrm{l}\left(250 \mathrm{ng} \mathrm{ml}^{-1}\right.$ in 0.05 mol sodium bicarbonate $\mathrm{I}^{-1}, \mathrm{pH}$ 9.6) of the primary capture antibody, a purified mouse monoclonal antiserum, clone 0220-518B7 (518B7) raised against the $\beta$ subunit of bovine LH (J. Roser, Department of Animal Science, University of California, Davis, CA), except for the first two wells (1a and $1 \mathrm{~b}$ ) which were used as plate/assay blanks. The plates were sealed and incubated overnight at $4^{\circ} \mathrm{C}$ or stored at $4^{\circ} \mathrm{C}$ until used. Before use, non-bound antiserum was removed from the wells by washing the plates five times with wash solution (0.15 mol NaCl ${ }^{-1}$ containing $0.05 \%(\mathrm{v} / \mathrm{v})$ Tween 20).

Before assay, standards (NIADDK-hLH-I-3, AFP-827OB, range $0.002-0.500 \mathrm{ng}^{-1}$ well $^{-1}$ ), serum (diluted between 1:10 and $1: 20$ ), peritoneal fluid (diluted $1: 20$ ) and all internal controls were diluted in MOPS assay buffer $(0.04 \mathrm{~mol} 3(\mathrm{~N}$ morpholino) propanesulfonic acid $\mathrm{I}^{-1}$ containing $0.015 \mathrm{~mol}$

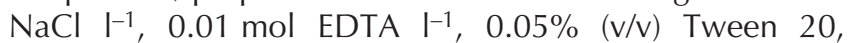
$0.005 \%(\mathrm{v} / \mathrm{v})$ chlorhexidine digluconate and $0.1 \%(\mathrm{w} / \mathrm{v})$ BSA, pH 7.2 (Sigma Chemical)). A $25 \mu$ l aliquot of MOPS assay buffer was pipetted across the entire plate, followed immediately by addition of $100 \mu$ l of appropriate standards, buffer (zero standard), diluted samples (serum or peritoneal fluid) and assay controls. Plates were sealed and incubated for $1 \mathrm{~h}$, after which time non-bound $\mathrm{LH}$ was removed from the wells by washing the plates as described previously. The enzyme-labelled second antibody, R76, (anti-hCG:HRP, $100 \mu \mathrm{l})$ was diluted to 1:1500 in MOPS assay buffer and pipetted across the entire plate. The plates were again sealed and the second antibody conjugate reaction was allowed to proceed for a further $1 \mathrm{~h}$. Non-bound second antibody was removed by washing, as described, followed by addition of $100 \mu \mathrm{l}$ substrate (2,2'-azino-bis(3ethylbenzthiazoline-6-sulphonic acid) diammonium salt (ABTS) (Sigma Chemical) or $100 \mu \mathrm{l}$ 3,3',5,5'-tetramethyl benzidine dihydrochloride (TMB) (Pierce, Rockford, IL). Conversion of the substrate by the enzyme, manifested as a colour change, was stopped after appropriate colour development (approximately $60 \mathrm{~min}$ for ABTS, 15-20 min for $\mathrm{TMB})$ by the addition of $100 \mu \mathrm{l}$ stop solution $(0.15 \mathrm{~mol}$ hydrofluoric acid $\mathrm{I}^{-1}$ for ABTS; 2.0 mol sulphuric acid $\mathrm{I}^{-1}$ for $\mathrm{TMB})$. Absorbance was measured in an automatic plate reader (Biotek Instruments Inc., Winooski, VT) at $405 \mathrm{~nm}$ for ABTS, $450 \mathrm{~nm}$ for TMB, and data were transferred to an interfaced computer (IBM) for analysis. Calibration curves were constructed by using weighted least-squares linear regression according to the method of Rodbard and Lewald (1970) to yield concentrations.

Comparison of other hLH assays: radioimmunoassay and hLH enzymeimmunoassay kit for determination of $L H$ in serum and peritoneal fluid

Samples of serum and peritoneal fluid $(n=19)$ from healthy women and women with endometriosis were selected randomly from the groups of subjects included in the present study. LH was assayed both by a traditional radioimmunoassay (Sufi et al., 1986) and by a commercial enzymeimmunoassay kit (Boehringer Mannheim, Barcelona). The results of these assays were compared with values determined by our enzymeimmunoassay. The purpose of these assays was to determine whether similar results could be obtained with other currently available LH assay systems.

\section{Assay validation}

The specificity of the combination of the two antibodies (518B7 and R76) in the sandwich enzymeimmunoassay was tested by calculating the percentage of crossreactivity to related protein hormones. Curves generated from assays of LH standards and serially diluted serum and peritoneal fluid samples were compared for parallelism in the enzymeimmunoassay. Human serum from women taking oral contraceptives (oral contraceptive serum) and containing a known added concentration of LH $\left(40 \mathrm{ng} \mathrm{ml}^{-1}\right)$ was also diluted serially and compared with the standard doseresponse curve for parallelism. Sensitivity was determined as the least amount of hormone that could be distinguished from zero concentration of standard as defined by the mass at $2 \mathrm{SD}$ above the mean of the zero absorbance. The precision of the assay was assessed by determination of intra-plate (24 aliquots of the same sample or control within the same plate), intra-assay (measurement of the same sample or control on different plates (inter-plate) in the same assay), and interassay coefficients of variation. Both interand intra-assay coefficients of variation were calculated by the method of Rodbard (1974). Accuracy of the assay was determined by the percentage recovery of exogenous, known amounts of $\mathrm{LH}$ that had been added to different pools of serum known to initially contain no $\mathrm{LH}$, and to pools of control serum or peritoneal fluid.

\section{Statistical analyses and calculations}

LH concentrations either in peritoneal fluid or serum of both groups of patients (women with endometriosis and healthy women) were compared by ANOVA and Student's $t$ test with the Bonferroni adjustment. LH concentrations were compared with the phase of the menstrual cycle in both groups. $P$ values $<0.05$ were considered significant. An LH concentration either in serum or peritoneal fluid $>2$ SD above the mean value for healthy women was considered abnormal. 
The sensitivity, specificity, diagnostic efficiency, and predictive value of the enzymeimmunoassay for $\mathrm{LH}$ in either serum or peritoneal fluid were calculated according to the methods of Wulff (1981) and Smiley and Peterson (1993). The sensitivity of a test expresses the probability that a woman with endometriosis will give a positive test. Sensitivity is determined in a population of subjects known to have endometriosis. Specificity of a test is the probability that a patient will give a negative test in the absence of endometriosis. Specificity is measured in a population of subjects known to be free of endometriosis. Efficiency of a test is the percentage of correct results regardless of whether they are positive or negative. Efficiency expresses the combined positive and negative accuracy of a test. As the diagnostic probabilities are relevant to the clinic diagnostic they have also been calculated. Predictive values predict the probability of the presence (positive predictive value) or absence (negative predictive value) of endometriosis, given a positive or a negative test, and are measured in a population of subjects that contains patients with and without endometriosis. Diagnostic probabilities are dependent on the sensitivity and specificity of the assay.

\section{Results}

\section{Characterization of antibodies}

The primary capture antibody (518B7) chosen for this enzymeimmunoassay, which was generated against the $\beta$ subunit of bovine $\mathrm{LH}$, has been well characterized for detection of $\mathrm{LH}$ and chorionic gonadotrophin (CG) in the serum of diverse mammalian species (Matteri et al., 1987; Illera et al., 1996; Munro et al., 1997). The enzymeimmunoassay crossreacted with human LH standard, which gave a dose-response curve parallel to the hCG standard dose-response curve and a minimum detection of $0.05 \mathrm{ng}$ $\mathrm{LH}$ per well. However, the enzymeimmunoassay did not crossreact with other human protein hormones (FSH, thyroid stimulating hormone (TSH)) tested, as evidenced by a lack of colour development in the assay. As the specificity of the sandwich enzymeimmunoassay is dependent on the determinant-specific monoclonal capture antibody, in this case 518B7, this allows for the use of a second, enzymelabelled antiserum that does not need to have a high degree of specificity. Hence, the polyclonal second antiserum, R76, was not tested for crossreactivity. However, this anti-hCG signal antiserum (R76) had a sensitivity of $>0.015 \mathrm{ng}$ hCG (WHO preparation 75/537) per tube in the competitive radioimmunoassay described by Lasley et al. (1985).

\section{Conjugate assessment}

Recovery of enzyme activity after conjugation was $87 \%$. A final dilution of 1:1500 of the anti-hCG-horseradish peroxidase conjugate in assay buffer was found to give both adequate colour development and low non-specific binding in the assay.
Validation of enzymeimmunoassay for $\mathrm{LH}$ in serum and peritoneal fluid of healthy women and women with endometriosis (sensitivity, precision, accuracy and parallelism test)

The range of the standard dose-response curve was 0.002-0.500 ng LH per well. The lowest concentrations of $\mathrm{hLH}$ that could be distinguished from zero concentration were $0.15 \pm 0.02 \mathrm{ng} \mathrm{ml}^{-1}$ serum $(100 \mu \mathrm{l}, 1: 10$ dilution) and $0.058 \pm 0.021 \mathrm{ng} \mathrm{ml}^{-1}$ peritoneal fluid $(100 \mu \mathrm{l}, \quad 1: 20$ dilution). The precision of the enzymeimmunoassay was assessed in a $5.0 \mathrm{ng} \mathrm{ml}^{-1}$ standard preparation of $\mathrm{LH}$, as well as in selected pooled serum and peritoneal fluid samples. The intra-plate (within-plate, 24 aliquots of the same sample) coefficient of variation for a $5 \mathrm{ng} \mathrm{ml}^{-1} \mathrm{LH}$ standard averaged $4.3 \%$, whereas for replicate measurements of serum samples and peritoneal fluid the coefficients of variation were 5.4 and $3.7 \%$, respectively. Mean intraassay coefficients of variation for pools of high, medium and low LH concentrations in serum and peritoneal fluid were $5.4,7.1$ and $9.8 \%$, respectively, whereas the average interassay coefficients of variation for the same pools were 6.4 , 8.8 and $12.1 \%$, respectively.

The accuracy of the enzymeimmunoassay was determined by measuring the recovery rates of known amounts of $\mathrm{LH}\left(0,1,5,10\right.$ and $\left.25 \mathrm{ng} \mathrm{m}^{-1}\right)$ that had been added to different pools of serum obtained from women taking oral contraceptives (oral contraceptive serum), as this pool of serum was readily available. The recovery rates (mean $\pm \mathrm{SE}$ ) were $96.54 \pm 1.87$ for the high (10.0 and $25.0 \mathrm{ng} \mathrm{ml}^{-1}$ ) and $94.58 \pm 4.65$ for the low (0.0-5.0 ng $\mathrm{ml}^{-1}$ ) concentrations of $\mathrm{hLH}$. The recovery rates for pooled control serum or peritoneal fluid to which $10 \mathrm{ng} \mathrm{hLH} \mathrm{ml}^{-1}$ had been added were $95.98 \pm 3.23 \quad(n=15)$ and $93.77 \pm 4.45(n=15)$, respectively.

LH standard concentrations were diluted in MOPS assay buffer and oral contraceptive serum, and each standard dose-response curve was compared in the assay to study the effects of human serum. A high control sample (40 ng $\mathrm{LH} \mathrm{ml} \mathrm{m}^{-1}$ in oral contraceptive serum) was also diluted serially in both MOPS assay buffer (decreasing volume of human serum per well) and oral contraceptive serum (constant volume of human serum per well) and these dilutions were run in parallel with the standard dose-response curves (Fig. 1). All of the dose-response curves are parallel, indicating that there is little or no effect of human serum on the LH enzymeimmunoassay. The standard curves are also parallel and identical whether $\mathrm{LH}$ standards are diluted in MOPS assay buffer or oral contraceptive serum.

In the same way, a single peritoneal fluid sample diluted serially in MOPS assay buffer gave a dose-response curve parallel to the LH standard dose-response curve (Fig. 2). All standards are diluted in MOPS buffer, and serum and peritoneal fluid samples are diluted at a point on the curve where there is still parallelism in the dilution curve (normally $1: 10$ or $1: 20$ for serum and 1:20 for peritoneal 


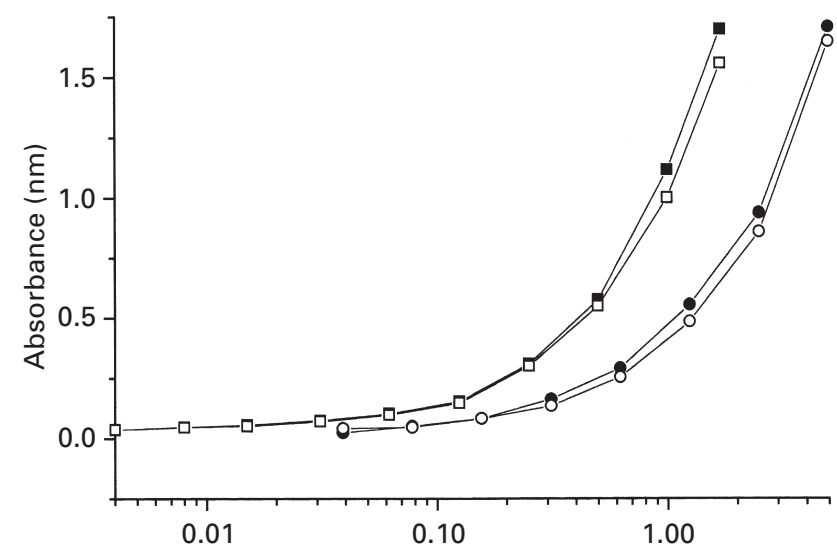

ng hLH per well or $\mu \mathrm{l} \times 10^{-1}$ human serum per well

Fig. 1. Serial dilutions of a known concentration $\left(40 \mathrm{ng} \mathrm{ml}^{-1}\right)$ of human $\mathrm{LH}(\mathrm{hLH})$ diluted in serum from women taking contraceptives (oral contraceptive serum; $\mathbf{\square}$ ) or in MOPS buffer ( $\square$ ). The displacement curves produced are parallel to those of standard LH dose-response curves in which LH standards were diluted in either oral contraceptive serum $(\bigcirc)$ or MOPS buffer

fluid) to use the enzymeimmunoassay in its simplest form for the measurement of LH in human serum or peritoneal fluid.

The simple regression analysis of serum and peritoneal fluid LH concentrations measured by the three different assays yielded the following results: a high correlation was found $(r=0.98)$ when the enzymeimmunoassay was compared with the enzymeimmunoassay kit. However, correlation was low when the enzymeimmunoassay was compared with the radioimmunoassay $(r=0.95)$, although that means only a divergent result from two subjects instead of one subject.

The clinical diagnostic validation parameters gave the following results: sensitivity of LH enzymeimmunoassay was $85.71 \%$ (of 56 endometriosis samples assayed, 48 were positive and eight were negative), specificity was $92.50 \%$ (of 40 healthy samples assayed, 37 were negative and 3 were positive) and efficiency was $88.54 \%$ (of 96 samples assayed, 85 were diagnosed correctly and 11 were false negative (eight samples) or false positive (three samples)). The diagnostic accuracy measured was as follows: positive predictive value was $94.11 \%$ and negative predictive value was $82.22 \%$.

\section{Concentrations of $\mathrm{LH}$ in serum and peritoneal fluid during the menstrual cycle of healthy women and women with endometriosis}

Serum $\mathrm{LH}$ values (mean $\pm \mathrm{SD}$ ) of healthy women were $4.52 \pm 2.03 \mathrm{ng} \mathrm{ml}^{-1}$, whereas women with endometriosis had serum $\mathrm{LH}$ values of $13.67 \pm 7.21 \mathrm{ng} \mathrm{ml}^{-1}(P<0.001)$. Healthy women had peritoneal fluid $\mathrm{LH}$ values of $5.65 \pm 2.43 \mathrm{ng} \mathrm{ml}^{-1}$, whereas peritoneal fluid $\mathrm{LH}$ values in women with endometriosis were significantly higher

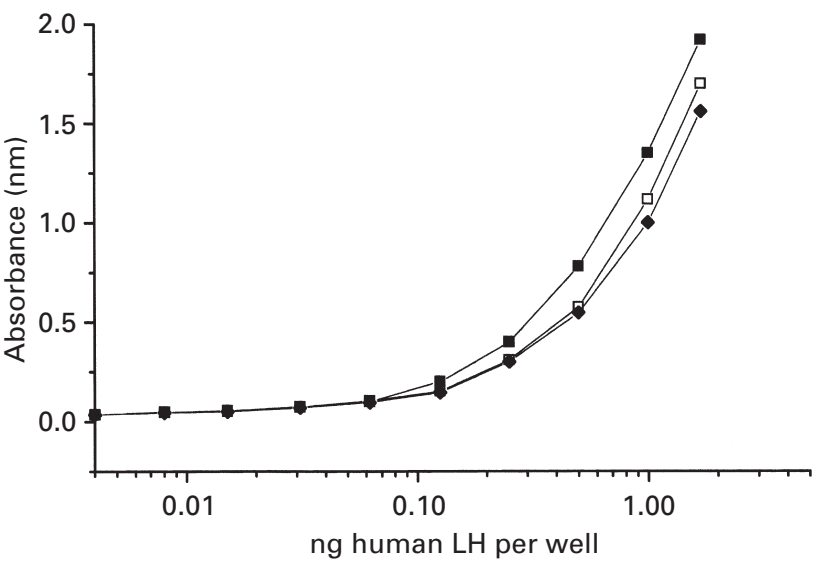

Fig. 2. Serial dilutions of human serum $(\diamond)$ and human peritoneal fluid ( $\mathbf{\square})$ in MOPS buffer were parallel with the LH standard doseresponse curve, also in MOPS buffer ( $\square$ ).

(64.06 $\left.\pm 16.44 \mathrm{ng} \mathrm{ml}^{-1} ; \quad P<0.001\right)$. These comparisons were calculated by using absolute $\mathrm{LH}$ values independent of the stage of the menstrual cycle.

$\mathrm{LH}$ concentrations varied depending on the stage of the menstrual cycle for both serum and peritoneal fluid and for healthy women and women with endometriosis. Healthy women had the following serum and peritoneal fluid values during the different phases of the menstrual cycle assayed: early proliferative: $2.17 \pm 0.22$ and $2.69 \pm 0.32 \mathrm{ng} \mathrm{ml}^{-1}$, respectively; proliferative: $6.46 \pm 0.23$ and $7.89 \pm 0.43 \mathrm{ng}$ $\mathrm{ml}^{-1}$, respectively; secretory: $3.92 \pm 0.60 \mathrm{ng} \mathrm{ml}^{-1}$ and $4.78 \pm 0.34 \mathrm{ng} \mathrm{ml}^{-1}$, respectively. For women with endometriosis the following serum and peritoneal fluid concentrations were measured at each stage of the cycle: early proliferative: $7.73 \pm 0.71$ and $50.35 \pm 4.01 \mathrm{ng} \mathrm{ml}^{-1}$, respectively; proliferative: $22.66 \pm 2.37$ and $76.27 \pm 4.51 \mathrm{ng}$ $\mathrm{ml}^{-1}$, respectively; secretory: $11.64 \pm 0.79$ and $65.07 \pm$ $4.40 \mathrm{ng} \mathrm{ml}^{-1}$, respectively. For both groups of women, serum and peritoneal fluid LH concentrations were highest in the proliferative phase (with the LH peak occurring during this phase) and lowest in the early proliferative phase. Comparisons made between serum versus serum, and peritoneal fluid versus peritoneal fluid LH concentrations at each phase of menstrual cycle indicated that there were significant differences in $\mathrm{LH}$ concentrations in all the cases analysed $(P<0.05)$, except for the case of peritoneal fluid versus peritoneal fluid in the proliferative and secretory phases of women with endometriosis. No significant differences were observed when comparing serum versus peritoneal fluid LH concentrations at all the stages of the menstrual cycle of healthy women, although peritoneal fluid LH concentrations were slightly higher compared with those of serum. In contrast, in women with endometriosis there were significant differences $(P<0.001)$ between serum and peritoneal fluid LH concentrations in all the cases analysed, with peritoneal fluid LH concentrations more than three times higher than those of serum. 
The different phases of the menstrual cycle are depicted (Fig. 3). During each phase, comparisons between serum $\mathrm{LH}$ and peritoneal fluid $\mathrm{LH}$ concentrations of both groups were performed, and significant differences were observed in all the cases analysed $(P<0.001)$.

Serum samples showed a positive test at $8.58 \mathrm{ng} \mathrm{ml}^{-1}$ $($ mean $+2 \mathrm{SD})$ of $\mathrm{LH}$ and peritoneal fluid samples at $10.51 \mathrm{ng} \mathrm{LH} \mathrm{ml}{ }^{-1}$ (mean $+2 \mathrm{SD}$ ). These results indicate that in the case of healthy women only three of 40 samples analysed overlapped with a positive test (false positives). These cases were peritoneal fluid samples of healthy women in the proliferative phase of the menstrual cycle. Only eight of 56 samples from women with endometriosis overlapped with a negative test. All these cases were diagnosed in serum samples, six of them in the early proliferative phase and two in the secretory phase of the menstrual cycle, both being results in the secretory phase near the limit of a positive test $\left(8.16\right.$ and $8.26 \mathrm{ng} \mathrm{LH} \mathrm{ml}^{-1}$, respectively). All the analyses performed in peritoneal fluid samples of women with endometriosis tested positive.

\section{Discussion}

Minimally invasive methods are needed increasingly for the development of markers to diagnose endometriosis in women. Hormone assays have been used for the diagnosis of several pathological disorders associated with infertility, including luteal phase defect (Jones and Madrigal Castro, 1970) and polycystic ovary syndrome (Homburg, 1996). While several markers for the diagnosis of endometriosis have been described (Pittaway, 1989; Lessey et al., 1994), the use of hormone assays has also been examined (Andrews, 1975; Chew et al., 1990; Khorram et al., 1993; Barry-Kinsella et al., 1994; Colacurci et al., 1996). The detection of serum or peritoneal fluid LH concentrations could provide a useful tool for examining the hormonal events associated with endometriosis in women. In the present study, women with endometriosis were observed to have increased peritoneal fluid and serum LH concentrations compared with healthy women without evidence of endometriosis.

Enzymeimmunoassays are generally less expensive, easier and safer to perform than other assay techniques (Munro and Lasley, 1988), and enzymeimmunoassay methods permit the use of antibodies with limited binding affinities and specificities. In contrast to competitive assays, reagents in enzymeimmunoassay systems can be used in excess. The present data demonstrate that the enzymeimmunoassay described in this report can be used for the measurement of $\mathrm{LH}$ concentrations in serum and peritoneal fluid from healthy women and women with endometriosis.

Monoclonal antibody techniques and the ability to select immunoglobulins that recognize individual epitopes have allowed specific, sensitive and precise immunoassay systems to be developed. The monoclonal antiserum, 518B7, can be produced in virtually unlimited quantity, providing a stable source of high quality antiserum.

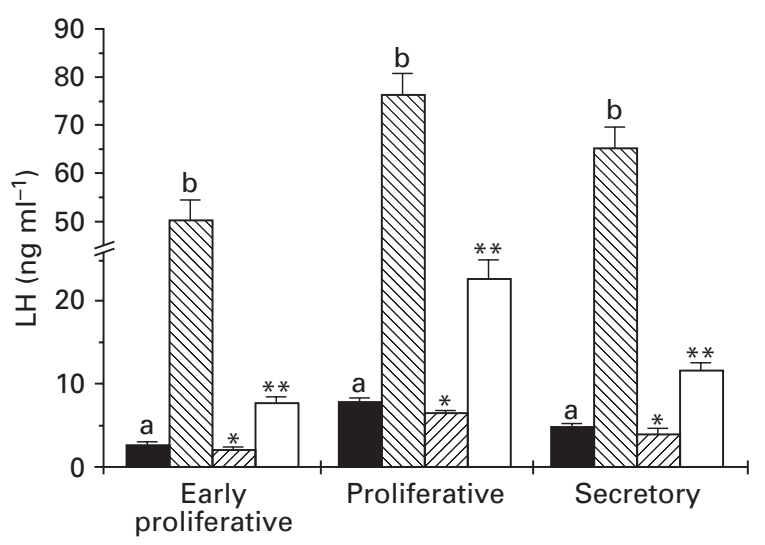

Fig. 3. Comparison between peritoneal fluid and serum LH concentrations in healthy women and women with endometriosis at different stages of the menstrual cycle. Peritoneal fluid ( $\square$ ) and

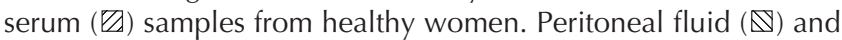
serum ( $\square$ ) samples from women with endometriosis. Values are mean $\pm \mathrm{SD}$. Values with different symbols ( ${ }^{a}$ versus ${ }^{b}$ and $*$ versus $\left.{ }^{* *}\right)$ within the same stage of the menstrual cycle are significantly different $(P<0.001)$.

Although the enzyme-labelled signal antibody is a polyclonal antiserum that has finite availability, this is unlikely to limit the general concept presented in this study. As the final $\mathrm{LH}$ recognition and specificity of the assay are determined by the specific monoclonal capture antibody, 518B7, and the signal antiserum does not require a high degree of specificity, there are probably a number of signal antibodies (including mAbs) that will perform as well as, if not better, than R76. This simple practical non-competitive enzymeimmunoassay does not require plate-blocking or overnight steps and, most importantly, does not require the chemical conjugation of extremely limited supplies of purified pituitary hormone preparations.

A basic enzymeimmunoassay requires an efficient and stable enzyme labelling of the second or signal antibody, as well as the ability to avoid matrix effects. The second enzyme conjugate used in the present study has retained $100 \%$ of its original activity when stored in $60 \%(\mathrm{v} / \mathrm{v})$ glycerol at both $4^{\circ} \mathrm{C}$ and $-15^{\circ} \mathrm{C}$ for 24 months (Matteri et al., 1987). The precision of this assay system is partially due to its ability to permit unbound materials to be separated from bound proteins by a simple but thorough washing step. This robustness in binding obviates the need for complicated separation steps required in other assay systems. The elimination of interference and the virtual absence of LH competitors are demonstrated by the recovery rates and parallelism of known amounts of $\mathrm{LH}$ when compared with the standard dose-response curves in both peritoneal fluid and serum. This non-isotopic enzymeimmunoassay for $\mathrm{hLH}$, which can be completed in $<3 \mathrm{~h}$, offers a stable, rapid and improved assay system compared with previously reported methods or commercially available enzymeimmunoassay kits, and has been developed and validated with materials that are readily available to all laboratories. 
This fact is of particular importance to laboratories that are unable to acquire the necessary licences or do not have the facilities to handle radioisotopes.

Our results in terms of diagnostic validation parameters demonstrated that the present enzymeimmunoassay has an increased sensitivity, specificity and efficiency comparable and even higher than other methods reported for human LH (Bouckaert et al., 1986; Chew et al., 1990; Kim-Brjörlund et al., 1991). The explanation of the false positives and negatives found in either serum or peritoneal fluid is related more to the variations of $\mathrm{LH}$ concentrations during the different phases of the menstrual cycle than to the technique used. Owing to this cycle-dependent variation, the clinician must take into account the day of the menstrual cycle on which the sample was taken in order to avoid false positive results. Such false positive results may occur if the serum or peritoneal fluid of healthy women is obtained coincident with the LH peak in the late proliferative phase. False negatives might also be determined in the serum of women with endometriosis during the early proliferative stage. The number of cases examined in the present study does not allow the diagnostic ranges for each stage of the menstrual cycle to be established but the results indicate that there are optimal times for measurement.

$\mathrm{LH}$ concentrations varied with the different phases of the menstrual cycle, both in serum and peritoneal fluid, and in healthy controls significant differences in LH concentrations during the menstrual cycle were observed in both peritoneal fluid and serum. LH concentrations are also higher in peritoneal fluid than in serum from the same patient, although these differences were not significant. Bouckaert et al. (1986) also reported higher concentrations of $\mathrm{LH}$ in peritoneal fluid than in serum and the differences were significant. In contrast, Kim-Brjörlund et al. (1991) found higher concentrations of $\mathrm{LH}$ in the serum of healthy women compared with peritoneal fluid, except during the early luteal phase when concentrations were equal. These authors attributed the differences in the reported results to the methods of dating of the oestrous cycle, the accuracy of the hormone assay and to the size of the study groups, explanations that could also be applied to the present data.

In the present study, in women diagnosed with endometriosis peritoneal fluid $\mathrm{LH}$ concentrations were significantly higher compared with serum LH concentrations during all the stages of the menstrual cycle, and both serum and peritoneal LH concentrations were significantly higher than in healthy women. However, the cycledependent pattern of $\mathrm{LH}$ concentrations was observed in serum only. Previous reports, using radioimmunoassay, have also demonstrated increased peritoneal fluid $\mathrm{LH}$ concentrations in women with endometriosis (Chew et al., 1990). Although this technique does not distinguish bioactive from immunoactive $\mathrm{LH}$, the high concentrations observed may account for the stimulatory effect of peritoneal fluid from endometriosis patients on granulosa cell progesterone secretion described in vitro (Whitehead et al., 1996). Furthermore, as gonadotrophin receptors have been reported in the endometrium (Reshef et al., 1990), the high LH concentrations may account for the alterations in the endometrial protein patterns noted in the peritoneal fluid of women with endometriosis (Joshi et al., 1986).

Bioactive substances such as LH in peritoneal fluid, especially when present at high concentrations, could also account for the infertility associated with endometriosis. Increased LH could contribute to the ovulatory disturbances noted in endometriosis, including luteinized unruptured follicle syndrome (Dhont et al., 1984; Dmowski et al., 1986), luteal phase defect (Grant, 1966; Li et al., 1991; Hirama and Ochiai, 1995) and anovulation (Soules et al., 1976; Hahn et al., 1986), as peritoneal fluid from rabbits with surgically induced endometriosis blocked implantation in otherwise normal animals. Similar data from human peritoneal fluid into mice corroborates the effects of human peritoneal fluid from endometriosis patients on implantation (Illera et al., 1995b). Altered expression of endometrial integrins has been observed in women with endometriosis (Lessey et al., 1994). It would be of interest to correlate such changes with concentrations of peritoneal LH in these women with apparent defects in uterine receptivity.

The enzymeimmunoassay described in the present study is likely to be useful beyond obstetrical diagnosis and biomedical research, and the application of this assay to serum and peritoneal fluid samples provides the attractive possibility that such a test could be included into the panel of markers for endometriosis.

hCG standard preparations were received from J. O'Connor (CR-127, Irving Center for Clinical Research, New York, NY) and the World Health Organization (1st International Reference Preparation, 75/537, National Institute for Biological Standards and Control, Holly Hill, Hampstead, London). Human luteinizing hormone (hLH, NIADDK-hLH-I-3 (AFP-827OB)) was obtained from the National Hormone and Pituitary Program, NIADDK, Bethesda, MD. This research was supported by $\mathrm{NICHD} / \mathrm{NIH}$ through cooperative agreement U54 HD-30476 (BL) as part of the Specialized Cooperative Centers Program in Reproduction Research, the National Cooperative Program on Markers of Uterine Receptivity for Blastocyst Implantation (HD 34824; BL).

\section{References}

Aeby TC, Huang T and Nakayama RT (1996) The effect of peritoneal fluid from patients with endometriosis on human sperm function in vitro. American Journal of Obstetrics and Gynecology 174 1779-1783

Andrews MC (1975) The effects of danazol on gonadotrophins and steroid blood levels in normal and anovulatory women American Journal of Obstetrics and Gynecology 121 817-827

ASRM (American Society for Reproductive Medicine) (1997) Revised American Society for Reproductive Medicine classification of endometriosis: 1996 Fertility and Sterility 67 817-821

Badawy SZA, Cuenca V, Marshall L, Munchback R, Rinas AC and Coble DA (1984) Cellular components on peritoneal fluid in infertile patients with and without endometriosis Fertility and Sterility 198 704-708

Barry-Kinsella C, Sharma SC, Cotell E and Harrison RF (1994) Mid to late luteal phase steroids in minimal stage endometriosis and unexplained infertility European Journal of Obstetrics and Gynaecology and Reproductive Biology 54 113-118

Bouckaert PXJM, Evers JLH, Doesburg WH, Schellekens LA, Brombacher 
PH and Rolland R (1986) Patterns of changes in glycoproteins, polypeptides, and steroids in the peritoneal fluid of women during the periovulatory phase of the menstrual cycle Journal of Clinical Endocrinology and Metabolism 62 293-299

Chew PCT, Loganath A, Gunasegaram R, Peh KL, Kottegoda SR and Ratnam SS (1987) A comparative study of peritoneal fluid concentrations of oestradiol-17 $\beta$, progesterone, and testosterone in controls and in patients with endometriosis Annals of the Academy of Medicine Singapore 16 344-346

Chew PCT, Peh KL, Loganath A, Gunasegaram R and Ratnam SS (1990) Elevated peritoneal fluid luteinizing hormone and prolactin concentrations in infertile women with endometriosis International Journal of Obstetrics and Gynaecology 33 35-39

Coddington CC, Oehninger S, Cunningham DS, Hansen K, Sueldo CE and Hodgen GD (1992) Peritoneal fluid from patients with endometriosis decreases sperm binding to the zona pellucida in the hemizona assay. A preliminary report Fertility and Sterility $\mathbf{5 7} 783-786$

Colacurci N, Fortunato N, De Franciscis P, Fratta M, Cioffi M, Zracone R and Cardone A (1996) Serum and peritoneal CA-125 levels as diagnostic test for endometriosis European Journal of Obstetrics and Gynaecology and Reproductive Biology 66 41-43

Dhont M, Serreyn R, Duvivier P, Vanluchene E, De Boever J and Vandekerckhove D (1984) Ovulation stigma and concentration of progesterone and estradiol in peritoneal fluid: relation with infertility and endometriosis Fertility and Sterility 41 872-877

Dmowski WP, Radwanska E, Binor Z and Rana N (1986) Mild endometriosis and ovulatory dysfunction. Effect of danazol treatment on success of ovulation induction Fertility and Sterility $\mathbf{4 6}$ 784-789

Drake TS, Metz SA, Grunert GM and O'Brien WF (1980) Peritoneal fluid volume in endometriosis Fertility and Sterility 34 280-281

Dufau ML, Pock R, Neubauer A and Catt KJ (1976) In vitro assay of LH in human serum: the rat intersticial cell testosterone (RICT) assay Journal of Clinical Endocrinology and Metabolism 42 958-969

Grant A (1966) Additional sterility factors in endometriosis Fertility and Sterility 17 514-519

Hahn DW, Carraher RP, Foldesy RG and McGuire JL (1986) Experimenta evidence for failure to implant as a mechanism of infertility associated with endometriosis American Journal of Obstetrics and Gynaecology 155 1109-1113

Halme J, Becker S and Wing R (1984) Accentuated cyclic activation of peritoneal macrophagues in patients with endometriosis American Journal of Obstetrics and Gynaecology 148 85-90

Haney AF, Muscata JJ and Weinberg JB (1981) Peritoneal fluid cell populations in infertility patients Fertility and Sterility 35 696-698

Harada T, Yoshioka H, Yoshida S, Iwabe T, Onohara Y, Tanikawa M and Terekawa N (1997) Increased interleukin-6 levels in peritoneal fluid of infertile patients with active endometriosis American Journal of Obstetrics and Gynecology 176 593-597

Hirama Y and Ochiai K (1995) Estrogen and progesterone receptors of the out-phase endometrium in female infertile patients Fertility and Sterility 63 984-988

Homburg R (1996) Polycystic ovary syndrome - from gynaecological curiosity to multisystem endocrinopathy Human Reproduction $\mathbf{1 1}$ 11-39

Hsu CC, Yang BC, Wu MH and Huang KE (1997) Enhanced interleukin-4 expression in patients with endometriosis Fertility and Sterility 67 1059-1064

Huang JC, Papasakelario C and Dawood MY (1996) Epidermal growth factor and basic fibroblast growth factor in peritoneal fluid of women with endometriosis Fertility and Sterility 65 931-934

Illera JC, Munro CJ and Bondurant RH (1995a) Development and validation of a simple, rapid, sandwich enzymeimmunoassay for the measurement of serum bovine and ovine LH concentrations Biology of Reproduction 5275 (Abstract)

Illera MJ, Rumen J, Yuan LW and Lessey BA (1995b) Peritoneal fluid from infertile women with endometriosis and aberrant endometrial integrin expression blocks embryo implantation in a mouse model The Endocrine Society 77th Annual Meeting P2-98 315 (Abstract)

Illera JC, Munro CJ, Silván G, Bondurant RH and Illera M (1996)
Development of a simple, rapid sandwich enzymeimmunoassay for the measurement of serum rat LH Journal of Physiology and Biochemistry 52 95-102

Illera JC, Munro CJ, Bondurant R, Silvan G and Illera M (1997) A sandwich enzymeimmunoassay for the measurement of swine plasma $\mathrm{LH}$ concentrations Theriogenology 47144 (Abstract)

Jones GS and Madrigal de Castro V (1970) Hormonal findings in association with abnormal corpus luteum function in the human: the luteal phase defect Fertility and Sterility 21 1-13

Joshi SG, Zamah NM, Raikar RS, Buttram VC, Jr, Henriques ES and Gordon $\mathbf{M}$ (1986) Serum and peritoneal fluid proteins in women with and without endometriosis Fertility and Sterility 46 1077-1082

Khorram O, Taylor R, Ryan I, Schall TJ and Landers DW (1993) Peritoneal fluid concentrations of the cytokine rates correlate with the severity of endometriosis American Journal of Obstetrics and Gynecology $\mathbf{1 6 9}$ 1545-1549

Kim-Briörlund T, Landgren BM and Hamberger L (1991) Peritoneal fluid volume and levels of steroid hormones and gonadotrophins in peritoneal fluid of normal and norethisterone-treated women Human Reproduction 6 1233-1237

Koninckx PR, Renaer M and Brosens I (1980a) Origin of peritoneal fluid in women: an ovarian exudation product British Journal of Obstetrics and Gynaecology 87 177-183

Koninckx PR, De Moor P and Brosens I (1980b) Diagnosed unruptured follicle syndrome by steroid hormone assay on peritoneal fluid British Journal of Obstetrics and Gynaecology 87 929-934

Lasley BL, Stabenfeldt GH, Overstreet JW, Hanson FW, Czekala N and Munro CJ (1985) Urinary hormone levels at the time of ovulation and implantation Fertility and Sterility 43 861-867

Lessey BA, Castelbaum AJ, Sawin SJ, Buck CA, Schinnar R, Wilkins B and Strom BL (1994) Aberrant integrin expression in the endometrium of women with endometriosis Journal of Clinical Endocrinology and Metabolism 79 643-649

Li TC, Dockery P and Cooke ID (1991) Endometrial development in the luteal phase of women with various types of infertility: comparison with women of normal fertility Human Reproduction 6 325-330

Loumaye E, Depreseter S, Donnez J and Thomas K (1984) Immunoreactive relaxin surge in peritoneal fluid of women during the midluteal phase Fertility and Sterility $\mathbf{4 2}$ 856-860

Matteri RL, Roser JF, Baldwin DM, Lipovetsky V and Papkoff H (1987) Characterization of a monoclonal antibody which detects luteinizing hormone from diverse mammalian species Domestic Animal Endocrinology 4 157-165

Morcos RN, Gibbons WE and Findley WE (1986) Effect of peritoneal fluid on in vitro cleavage of 2-cell mouse embryos: possible role in infertility associated with endometriosis Fertility and Sterility 44 678-683

Munro CJ and Lasley BL (1988) Non-radiometric methods for immunoassay of steroid hormones. In Nonradiometric Assays: Technology and Application in Polypeptide and Steroid Hormone Detection pp 289-329 Eds BD Albertson and FP Haseltine. Alan R Liss, New York

Munro CJ, Laughin LS, Illera JC, Dieter J, Hendrickx AG and Lasley BL (1997) ELISA for the measurement of serum and urinary chorionic gonadotrophin concentrations in the laboratory macaque American Journal of Primatology 41 307-322

Nothnick WB, Curry TE, Jr, Muse KN, London SN and Vernon MW (1994) Detection of a unique 32-kd protein in the peritoneal fluid of women with endometriosis Fertility and Sterility $61288-293$

Noyes RW, Hertig Al and Rock J (1950) Dating the endometrial biopsy Fertility and Sterility $13-25$

Oosterlynck DJ, Meuleman C, Waer M and Koninckx PR (1994) Transforming growth factor- $\beta$ activity is increased in peritoneal fluid from women with endometriosis Obstetrics and Gynaecology 83 287-292

Pittaway DE (1989) Assay characteristics of the immunoradiometric method for CA-125 Fertility and Sterility $\mathbf{5 1}$ 348-350

Punnonen J, Teisala K, Ranta H, Bennett B and Punnonen R (1996) Increased levels of interleukin-6 and interleukin-10 in the peritoneal fluid of patients with endometriosis American Journal of Obstetrics and Gynecology 174 1522-1526 
Reshef E, Lei ZM, Rao CV, Pridham DD, Chegini N and Luborsky IL (1990) The presence of gonadotropin receptors in nonpregnant human uterus, human placenta, fetal membranes and decidua Journal of Clinical Endocrinology and Metabolism 70 421-430

Rodbard D (1974) Statistical quality control and routine data processing for radioimmunoassays and immunoradiometric assays Clinical Chemistry $201255-1270$

Rodbard D and Lewald JE (1970) Computer analysis of radioligand assay and radioimmunoassay data Acta Endocrinologica (Copenhagen) 64 79-103

Ryan IP, Tseng JF, Schriock ED, Khorram O, Landers DV and Taylor RN (1995) Interleukin-8 concentrations are elevated in peritoneal fluid of women with endometriosis Fertility and Sterility 63 929-932

Sampson JA (1924) Benign and malignant endometrial implants in the peritoneal cavity and their relation to certain ovarian tumors Surgery Gynecology and Obstetrics 38 287-311

Smiley LE and Peterson ME (1993) Evaluation of a urine cortisol:creatinine ratio as a screening test for hyperadrenocorticism in dogs Journal of Veterinary Internal Medicine 7 163-168

Soules MR, Malinak LR, Bury R and Poindexter A (1976) Endometriosis and anovulation: a coexisting problem in infertile females American Journal of Obstetrics and Gynecology 125 412-417

Spearow JL and Trout BA (1987) Development of a sensitive enzyme-linked immunosorbent assay for cattle, sheep, rat, and mouse luteinizing hormone Biology of Reproduction 37 595-605

Sueldo CE, Lambert H, Steinleitner A, Rathwick G and Swanson J (1987) The effect of peritoneal fluid from patients with endometriosis on murine sperm-oocyte interaction Fertility and Sterility 48 697-699

Sufi SB, Donaldson A and Jeffcoate SL (1986) WHO Program for the Provision of Matched Assay Reagents. Method Manual. Geneva, Switzerland

Syrop CH and Halme J (1987) Peritoneal fluid environment and infertility Fertility and Sterility $\mathbf{4 8} 1-9$
Taketani M, Kuo TM and Mizuno M (1992) Comparison of cytokine levels and embryo toxicity in peritoneal fluid in infertile women with untreated or treated endometriosis American Journal of Obstetrics and Gynaecology 167 265-270

Taskin O, Guidice L, Mangal R, Dunn RC, Dsupin BA, Poindexter AN and Wiehle RO (1996) Insulin-like growth factor binding proteins in peritoneal fluid of women with minimal and mild endometriosis Human Reproduction 11 1741-1746

Weinberg JB, Haney AF, Xu FJ and Ramakrishnan S (1991) Peritoneal fluid and plasma levels of human macrophage colony-stimulating factor in relation to peritoneal fluid macrophage content Blood 78 513-516

Whitehead SA, Peattie AB, Shakil T and Suntharalingham J (1996) Endometriosis and polycystic ovary syndrome: enhanced stimulatory effect on progesterone release from human granulosa-lutein cells Fertility and Sterility 66 487-489

Wilson MB and Nakane PK (1978) Recent developments in the periodate method of conjugating horseradish peroxidase (HRP) to antibodies. In Immunofluorescence and Related Staining Techniques pp 215-224 Eds W Knapp, K Holubar and C Wick. Elsevier-North Holland Biomedical Press, New York-Amsterdam

Wulff HR (1981) Rational Diagnosis and Treatment Blackwell Scientific Publications, Oxford

Yoshida T, Suzuki K, Cho F and Honjo S (1987) Serum chorionic gonadotropin levels determined by radioreceptorassay and early diagnosis of pregnancy in the cynomolgus monkey (Macaca fascicularis) American Journal of Primatology 12 101-106

Received 5 October 2000.

First decision 17 November 2000.

Accepted 15 January 2001. 